\title{
State control (supervision) and the regulatory guillotine in the field of higher education in the Russian Federation
}

\section{Controle estatal (supervisão) e a guilhotina regulatória no campo do ensino superior na Federação Russa}

\section{Control estatal (supervisión) y guillotina reguladora en el campo de la educación superior en la Federación de Rusia}

\author{
Maxim Kozyrev $^{1}$ iD, Evgeniya Jukova² ${ }^{\text {iD }}$, Polina Palekhova ${ }^{3}$ iD, \\ Alexander Shumarov ${ }^{4}$ iD, Rinat Faizulin ${ }^{1}$ iD
}

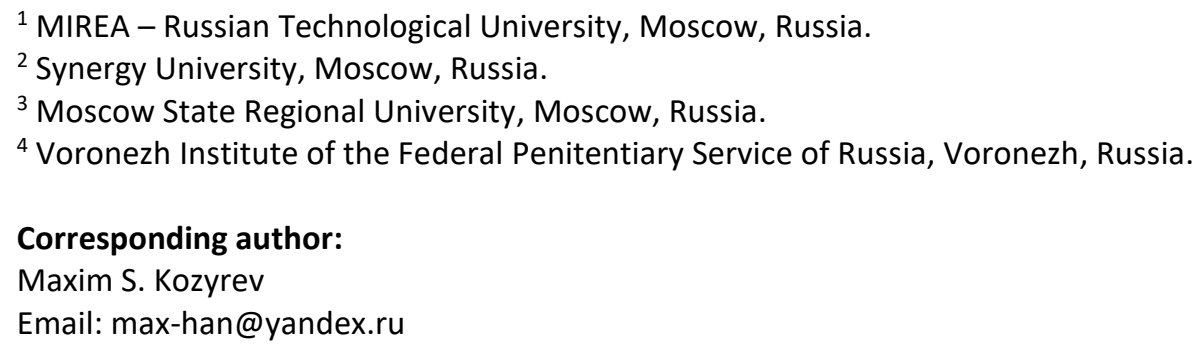

How to cite: Kozyrev, M. S., Jukova, E. E., Palekhova, P. V., Shumarov, A. P., \& Faizulin, R. V. (2022). State control (supervision) and the regulatory guillotine in the field of higher education in the Russian Federation. Revista Tempos $e$ Espaços em Educação, 14(33), e17220. http://dx.doi.org/10.20952/revtee.v14i33.17220

\begin{abstract}
The purpose of the article is to characterize current status of state control (supervision) in higher education in accordance with the implementation of the regulatory guillotine measures. The results of the research led the authors to the following conclusions. First of all, foreign expertise results in understanding the necessity of lobbying by non-governmental organizations. Otherwise, state regulators will operate precisely in their interests. Secondly, current administrative regulation of higher education is based on an inefficient monitoring system with redundant permissions of the Federal Service for Supervision in Education and Science (Rosobrnadzor). Thirdly, there is no reason to believe that the implementation the regulatory guillotine model can change the situation efficiently. It is more probable that the reduction of the intensity of control will lead to a net rise of latent offenses for educational institutions' management. To eliminate these problems, the authors suggest implementing of monitoring system for the activities of higher educational establishment as well as for regulator's actions with a monetization of these relations.
\end{abstract}

Keywords: State control (supervision). Higher education. The regulatory guillotine. Russia. 


\section{RESUMO}

O objetivo do artigo é caracterizar a situação atual do controle estatal (supervisão) no ensino superior de acordo com a implementação das medidas normativas da guilhotina. Os resultados da pesquisa levaram os autores às seguintes conclusões. Em primeiro lugar, a experiência estrangeira resulta na compreensão da necessidade de lobby por organizações não governamentais. Caso contrário, os reguladores estaduais irão operar precisamente em seus interesses. Em segundo lugar, a regulamentação administrativa atual do ensino superior é baseada em um sistema de monitoramento ineficiente com permissões redundantes do Serviço Federal de Supervisão em Educação e Ciência (Rosobrnadzor). Em terceiro lugar, não há razão para acreditar que a implementação do modelo de guilhotina regulatória pode mudar a situação de forma eficiente. É mais provável que a redução da intensidade do controle leve a um aumento líquido de ofensas latentes para a gestão de instituições de ensino. Para eliminar esses problemas, os autores sugerem a implantação de sistema de monitoramento das atividades dos estabelecimentos de ensino superior, bem como das ações do regulador com uma monetização dessas relações.

Palavras-chave: Controle estatal (supervisão). Ensino superior. A guilhotina reguladora. Rússia.

\section{RESUMEN}

El propósito del artículo es caracterizar el estado actual del control estatal (supervisión) en la educación superior de acuerdo con la implementación de las medidas reglamentarias de guillotina. Los resultados de la investigación llevaron a los autores a las siguientes conclusiones. En primer lugar, la experiencia extranjera da como resultado la comprensión de la necesidad de cabildeo por parte de las organizaciones no gubernamentales. De lo contrario, los reguladores estatales operarán precisamente en sus intereses. En segundo lugar, la regulación administrativa actual de la educación superior se basa en un sistema de seguimiento ineficaz con permisos redundantes del Servicio Federal de Supervisión en Educación y Ciencia (Rosobrnadzor). En tercer lugar, no hay razón para creer que la implementación del modelo de guillotina reguladora pueda cambiar la situación de manera eficiente. Es más probable que la reducción de la intensidad del control conduzca a un aumento neto de delitos latentes para la gestión de las instituciones educativas. Para eliminar estos problemas, los autores sugieren implementar un sistema de seguimiento para las actividades del establecimiento de educación superior, así como para las acciones del regulador con una monetización de estas relaciones.

Palabras clave: Control estatal (supervisión). Educación más alta. La guillotina reguladora. Rusia.

\section{INTRODUCTION}

State control (supervision) has been and is a public administration component of great importance. Its absence makes the administration itself meaningless. Although the opposite is also true: executive state control at least paralyzes public relations or at most leads them to the side business with a consequent criminalization. Therefore, it is important to strike a balance. On the one hand, state control (supervision) shall not prevent the existence of normal public relations and functions of the social institutions, and, on the other hand, its minimization shall not lead to total deregulation.

The search for the balance has been the goal of reform of state control (supervision) system since 2019, which designates by the colorful term the "regulatory guillotine". This term proposed by The Jacobs, Cordova \& Associates consulting company was firmly integrated into the media space of Russian public administration. It didn't end with the speeches of persons holding senior public positions (Intrefaks, 2019; Sovremennyy predprinimatel', 2019). The Russian Government actively implements some measures, which are related to the regulatory guillotine. In essence, they are boiled down to revealing and reducing the redundant regulatory requirements to decrease the burden on the business (Analytical Centre under the Government of the Russian Federation, 2021; 
Feynberg, 2019; Government of the Russian Federation, 2019, May 29). However, the question about the consequences of such measures remains open. Given the fact that some countries (for instance, Ukraine) have entirely opted out of the use of the regulatory guillotine, explaining their refusal by the appearance of a regulatory vacuum, which inevitably affects the quality of public administration, the feasibility of implementation of such measures is questionable.

The excessive state control (supervision) in many spheres of social production is beyond question. But, meanwhile, there is no need to succumb without a backward glance to the pressure of business communities or other lobbyists, which are aimed at eluding state supervision in general. Besides, several spheres of public relations (particularly, health care, education, housing construction, and public utilities) are of key importance in social reproduction and human existence. As a result, the citizens - the customers of goods and services (in a broad sense) - will be the ones to pay for all the excesses in this area.

Many spheres of state regulation have been "guillotined". The field of higher education has not been spared it, either. On 4 June 2019 Prime Minister of the Russian Federation approved the list of the federal executive authorities to perform the functions of laws and regulations in the areas of state control (supervision), and the federal executive authorities exercising monitoring and surveillance functions, which participate in the realization of the "regulatory guillotine" mechanism, types of federal-state control (supervision) implemented by the federal executive authorities that must be covered by the "regulatory guillotine" mechanism (Government of the Russian Federation, 2019, July 4). This list includes the Ministry of Science and Higher Education of the Russian Federation and the Federal Service for Supervision in Education and Science, and also, respectively, federal-state control over the educational quality, federal-state control in the field of education, and license control over the professional educational activities.

Under such circumstances, the evaluation of the efforts to reform the monitoring and surveillance functions in the field of higher education is an issue of crucial importance.

\section{REVIEW OF THE LITERATURE}

The Russian Government's initiative of the reform of control (supervision) activity has provoked the emergence of tens of scientific works devoted to the "regulatory guillotine". Most often, the articles describe the mechanism and the anticipated positive effects of the latter, the necessity to reduce and unify the regulatory requirements, to establish clear operating rules for the regulators in different areas of social production (Astakhov, 2019; Korenkov et al., 2019; Kotsanopoulos \& Arvanitoyannis, 2017; Kozyrev et al., 2019; Litvinova and Romanova, 2020; Martynov, 2019; Maslennikova et al., 2020; Mitrokhin, 2019; Parker \& Kirkpatrick, 2012; Red'ko, 2020; Sovremennyy predprinimatel', 2019; Yuzhakov et al., 2019; Yuzhakov et al., 2020), including the sphere of education (Aniskina et al., 2019; Arapov et al., 2018; Darda \& Zernov, 2020; Didikin, 2019; Filippov et al., 2020; Manyushis, 2020; Margolin, 2019; Motova, 2020; Mutsalov \& Arsamirzayeva, 2021; Safonkina et al., 2012; Sokolov, 2020).

In these publications, there is an obvious optimism concerning future interrelations between various supervised organizations and governmental control (supervision) authorities. Alarmism in this instance is not a trend of scientific thought. The opinions about the insufficiency (Lopatina, 2020) or even inadvisability (Tsypkina, 2019) of the proposed measures of the "regulatory guillotine" are extremely rare. The proposed negative results of the "regulatory guillotine" and also the ways of overcoming them have remained poorly researched issues. The article is one of the few attempts to fill that gap. 


\section{RESEARCH METHODS}

The document analysis was primarily used as the main research method. The objects of the study were normative legal acts (laws and regulations), speeches of persons holding public office and civil service, scientific publications (articles in journals and proceedings of conferences). Not only were the sources of information on the Russian case analyzed, but also the publications on the current state of affairs in foreign countries. Accordingly, the method of comparative analysis was additionally applied.

It is worth pointing out the use of observation techniques made by the authors with their direct engagement as a complainant in the control (supervision) activities of public authorities. It was the impression of the latter that became the motive for writing this article.

\section{RESEARCH RESULTS}

And what about foreign countries? The development and the beginning of the implementation of the "regulatory guillotine" mechanism in foreign countries are attributed to the eighties of the last century and are associated with Sweden (Aleksandrov, 2019). More recently, similar experiences of reforms of control and supervision activity had been applied to some extent in Italy, Ireland, Great Britain, Mexico, South Korea, Hungary, Kenya, Moldova, Japan, Thailand, etc. Although, a similar bright marketing slogan was used not in all cases, however, there was a distinctly observed reduction of the intensity of state "protection" with various spheres of social production in these countries.

Usually, in such cases, the field of higher education turned out to be not the main one but, though, somehow was affected by the reform of state control. Examples can be found in many states.

In particular, the Government in Japan since the 2000s has taken the path of providing an opportunity for private corporations to manage universities, to simplify the rules of admission for foreigners to enter the national higher educational institutions, including the postgraduate programs. The reason for such metamorphosis is the lobbying by large corporations, for which the training of graduate students becomes more and more costly. Undoubtedly, the significant mismatch between the labor market and the quality of education demonstrates the dysfunctions and isolationism of higher education, which must be corrected somehow. But it is equally undeniable that the overarching theme, in this case, is the companies' drive for transferring the costs of such training from private companies to the state. In addition, the first ones have been able to use the capacity of foreign education systems for their good (Japan fact sheet, 2015).

The Government's policy in Ireland is aimed at the increase of the attractiveness of higher education on a global scale, for which a special marketing strategy was developed, and the corresponding authority and autonomy were granted to universities. It is fair to mention that the Irish Government does care not only about the increase of financial independence of national universities (i.e. the reduction in revenues), but also about the rise of the educational availability among the youth and other socially vulnerable groups (women, the elderly and the disabled) (Department of the Taoiseach, 2009).

Great Britain follows a similar path by transferring to universities the right to set their tuition fees for students independently. Moreover, the major trends of the "regulatory guillotine" in the United Kingdom are the granting of autonomy to educational institutions of all levels both in the questions of their funding and their self-management. The volume of this autonomy is inversely proportional to the total amount of their financial support from the state. The process of deregulation of higher education in Great Britain is also interesting because the number of new regulations has increased in proportion to the statements of the Government concerning the reduction of the regulatory requirements (Ambler et al., 2007). 
The implementation of the "regulatory guillotine" in the Kingdom of Thailand has been more controversial. Even though the right of independent civic associations to participate in public administration was enshrined in the Constitution of 2007, the mechanism of civilian control and self-government had never been established (Ondee \& Pannarunothai, 2008). The de facto denial of the ruling elite of Thailand of deregulation and delegation of authority to civil society institutions has been particularly tangible in the field of higher education. It is no accident, therefore, that the main participants in the protests of 2020 were university students.

The experience of the Netherlands is extremely curious in the context of this research, and it has been reproduced to some extent by many continental European countries (Austria, Belgium, Denmark, Spain, Portugal, Sweden, Finland). The Netherlands Government declined detailed state control and supervision in favor of civilian control. The State Inspection of Higher Education monitors the general state of higher education, the Association for the Netherlands Universities' Cooperation - an independent non-governmental organization - is the "detachment of deep drilling" (Kokhanov, 2016, p. 520). The latter, besides these, presents the interests of universities and actively lobbies them in state bodies.

As an intermediate result of the analysis of foreign experience in the implementation of the "regulatory guillotine", it must be concluded that the achievement of the stated objectives can be possible only under the following conditions. Firstly, it is important to have heavy lobbying whose weight can overcome the resistance of the conservative part of bureaucracy unwilling to share its power and authority. The process of achieving the goals of the reform will become easier if they are in the line with the interests of large companies. Then they will take on the lobbying role by their choice. Secondly, the reduction in state expenditures must be very significant in order to be "worth the trouble" and thereby must allow getting supporters within the state bureaucracy.

Russian state of affairs. At the meeting of the Public Council under the Federal Service for Supervision in Education and Science, it was expressed for the transition from formal control procedures, when the data is checked on paper, towards the assessment of the real knowledge, the shift of emphasis from inspections and penalties on the facts of revealed violations towards the process of monitoring and formulation of recommendations for the development, the realization of measures to prevent offenses, the differentiation of approaches to the regulation of control and supervision activities according to levels and types of education, the engagement of representatives of employers to the process of monitoring of higher and specialized secondary education.

Meanwhile, the "regulatory guillotine" model is based on avoiding checks and penalties as the main priorities and the usage of monitoring and recommendations for the development.

Besides, any excess outdoor control and supervision, such as outdoor documentary inspection and expertise during the state accreditation, must be eliminated. In the selection of control and supervision activities, the risk-oriented approach should be used, whereby the educational institutions will be subject to permanent monitoring to consider them as one of the four risk categories: low risk, moderate risk (planned control every 2-6 years), significant risk (planned control every 1-4 years) and extremely high risk (planned control once or twice a year) (Federal Service for Supervision of Education and Science, 2019).

The stated objectives are to be welcomed. However, "the devil is in the details". And in this case "The Lord of Hell" is inciting the following question: whether the "regulatory guillotine" leads to deregulation of the whole sphere of higher education?

The use of monitoring, on which the Rosobrnadzor significantly relies, as the basis for control and supervision measures currently causes the deserved reproaches for formalism, inefficiency, and replacing the reality with the illusion of quality control over education (Margolin, 2019). Even if a significant change in the assessment system of the quality of higher education is occurred, with the claimed reduction of control and supervision pressure on universities the improvements can't be expected. Many institutions of higher education have falsified, overrated, or distorted by other 
means the requested data on monitoring indicators recently, and there is no reason to believe that the "regulatory guillotine" will become a magic impetus for the heads of such educational organizations to revise their worldview in this regard, which will be translated into socially responsible behavior.

The mechanism of efficient compliance control over the conformity of the credibility of data provided by educational organizations during the quality monitoring of education has not been introduced either by Rosobrnadzor or its opponents.

Moreover, the process of avoiding unscheduled inspections takes the universities out of Rosobrnadzor's control. Indeed, the reduction of requirements for educational institutions makes the scheduled inspections (when the organization is warned) poorly burdensome, especially for the unfair educational organizations.

Seemingly, the depravity of the current situation and its estimated substitutions are minimized through the jurisdictional activity of Rosobrnadzor, that is, the legal proceedings on administrative violations.

But herein, too, the pitfalls exist.

The powers of Rosobrnadzor in this part of state control (supervision) are narrowed. The regulator has no right to examine cases of administrative offenses in education but has only the authority to carry on the administrative investigations (to settle administrative offense reports). The final decision rests with the court, not the regulator.

The initiation of administrative proceedings (filing of administrative offense report) is left to the discretion of Rosobrnadzor. The responsibility of officials of these organizations for irregular administrative proceedings is not foreseen in current Russian legislation. The law does not grant the complainant, who has reported an offense, the right to appeal the refusal to the court if the appellant is not an affective party.

In addition, there is a discrepancy between the operational requirements for educational activities and the special part of the Code of the Russian Federation on Administrative Offenses, where the dispositions of administrative offenses are enshrined, i.e. the requirements exist, but the violation of the requirements for most of them does not establish direct liability. As an example, there can be cited the norms established by the Russian Government Decree of 10 July 2013 No. 582 "On the Adoption of the Rules for Posting on the Official Website of Educational Organizations in Information and Telecommunication Network 'The Internet' and the Updating of Information on Educational Organization" (Government of the Russian Federation, 2013, July 10).

Failure to comply with the requirements of this Decree can be qualified in terms of part 2 article 5.57 of the Code of the Russian Federation on Administrative Offenses (State Duma of the Federal Assembly of the Russian Federation, 2001), i.e. violation or illegal limitation of students' rights and freedoms provided by law, or violation of the established procedure for realization of specified rights and freedoms. In particular, there is also the limitation of students' freedom of information enshrined in paragraph 10 part 1 article 34 of the Federal Law "On Education in the Russian Federation" of 29 December 2012 No. 273-FZ (State Duma of the Federal Assembly of the Russian Federation, 2012).

However, such a chain of regulatory requirements (there is one by-law among them) leads to a problem of extended interpretation of the administrative legislation that is unacceptable according to the legal stance of the highest courts (Constitutional Court of the Russian Federation, 2014; Supreme Court of the Russian Federation, 2016).

In the case of revealing the violation of such rules, Rosobrnadzor is obliged to make an order to rectify discovered violations (by the way, it is the pre-trial restriction, not the responsibility), but again the penalty for failure to comply with this responsibility is not provided by the administrative legislation. 
Eventually, the following defects of the system of state control (supervision) in the field of higher education can be stated:

- the inefficiency of the system of monitoring in the field of higher education;

- the lack of administrative responsibility for the violation of many regulatory requirements for educational institutions;

- the lack of administrative responsibility for the violation of the norms of the proceedings for administrative offenses by jurisdictional bodies' officials;

- the lack of full-fledged rights of citizens to advocate for an unlimited set of people (besides the right of access to the public administration bodies) in the case of revealing the violations.

The implementation of the "regulatory guillotine" measures (in particular, the rejection of unscheduled inspections) would only exacerbate these defects. It can be predicted that after the procedures of state licensing and accreditation (if they are not cut by the "guillotine") the university will be no longer under the regulatory protection of state supervision. Students, their parents, and also employers and the labor market, in general, will pay for the deregulation of the sphere of higher education, because it will lead to the decline of education quality.

Undoubtedly, excessive regulation should be eliminated. Especially, when the regulator takes a strictly formal approach during inspections, accreditation and licensing. Only the documents provided by the university are evaluated, but not the real quality of education. The experiment in independent assessment of students' knowledge was conducted by Rosobrnadzor in 2015-2017 and was only the experiment without any consequences for public administration in the field of higher education (Federal Service for Supervision of Education and Science, 2017). However, there is a doubt whether they throw the baby out with the bathwater while implementing the promised reforms.

According to the authors, the quality of regulation in the field of described social relationships while implementing the goals of the "regulatory guillotine" can be improved if civil control is put into practice in public administration. To this effect, the complainant's rights should be enhanced. For instance, to provide the complainant with an opportunity to appeal against the actions of jurisdictional bodies during the administrative offense proceedings. To stimulate civil engagement, the transfer of a part of the fine to the complainant should be made, if the latter provides comprehensive evidence of the offender's guilt.

The extension of jurisdictional bodies' powers (primarily Rosobrnadzor) will also be required to consider cases of administrative offenses in the field of education and will serve as the first instance in this case. The extension of powers should be accompanied by the increased responsibility of the complainants as well as the jurisdictional bodies and the introduction of corresponding norms in the Code of the Russian Federation on Administrative Offenses. This approach is not new in domestic administrative legislation, but as has already been noted, Rosobrnadzor for some reason has no authority to consider cases on administrative offenses.

The majority of punishments in the field of higher education should be converted to fines to impose the monetary penalty on the offender. Moreover, such monetization must be extended to the heads of the universities, as well as the jurisdictional bodies' officials and the complainants. The opportunities for the punishment of legal entities (i.e. the universities as a whole, but not their heads) must be strictly limited because it can harm the staff and students who should not be responsible for the actions of the managers of educational organizations.

Another condition of civil control efficiency is the openness of universities' activities. The documents that prove the achievement of performance benchmarks in the educational system should be posted on the site of the educational organization. For example, there should be posted not only the current-year admission orders of the rector with personal students' scores for the Unified State Examination but also the rector's orders over the previous several years. Moreover, if 
the indexes of employment of graduates are on the conscience of the university, it is advisable to oblige the latter to provide verifiable sources of information.

The implementation of the united information system for higher education, where any interested person can find not only the monitoring data of the universities (as it is now) but also the information that uses as a basis for the formulation of indicators (for instance, the aforementioned rector's admission orders with personal students' scores for the Unified State Examination). The additional reason for the implementation of this information system is the fact that the education organization forms the site structure on its own, frequently being oriented on usability and userfriendliness for university entrants and students, but not the inspection body. In this case, the latter can be faced with numerous difficulties while searching for the needed information. The development of this information system of a homogeneous structure eliminates the issue.

Transparency makes civil control in the field of higher education total, expanding the number of prospective inspectors to the number of capable citizens of the country. This total control will imply legal awareness of the management raising it to a currently unattainable level.

In fairness, it should be mentioned that current Russian legislation ensures certain possibilities for conducting inspections based on information received from organizations and citizens.

So, according to paragraph 5 article 93 of the Federal Law "On Education in the Russian Federation", the grounds for inspections of educational organizations as a part of state control (supervision) in education along with the grounds provided by the Federal Law on 26 December 2008 No. 294-FZ "On Protection of the Rights of Legal Entities and Individual Entrepreneurs in Implementation of State Control (Supervision) and Municipal Control" (State Duma of the Federal Assembly of the Russian Federation, 2008) are the identifications by control and supervision bodies of violations of the legislation, including the federal educational standards' demands, in education based on monitoring data in the system of education specified in article 97 of this Law.

According to point 2 paragraph 5 of the Government Decree "On Implementation of Monitoring of the Education System" (Government of the Russian Federation, 2013, August 5) (along with "The Rules of Monitoring of the Education System"), the collection, processing, and analysis of information, while monitoring the quality control of education and revealing violations of the requirements of legislation on education in the Russian Federation, are exercised by the Federal Service for Supervision in Education and Science.

Under the Decree, such monitoring is carried out through the federal statistical observations, surveys, including sociological surveys, of educational organizations' activities posted on the official websites of educational institutions in information and telecommunication network "The Internet", the information published in mass media, and also the information received by public authorities, executive authorities of federal subjects of the Russian Federation and local authorities from citizens and organizations.

However, as on previous occasions, there is no responsibility of Rosobrnadzor to conduct an inspection. The solution to this issue leaves Rosobrnadzor's discretion.

\section{CONCLUSION}

The following key points will serve as conclusions.

1. The existing administrative regulation of higher education is based on an inefficient monitoring system with the excessive authority of Rosobrnadzor. Civil control over both the regulator and universities is almost lacking

2. There is no reason to believe that the implementation of the "regulatory guillotine" model will somehow change the situation effectively. It is more likely that the reduction of management intensity will lead to a net rise in latent offenses by the heads of educational organizations. No 
proposals to establish the mechanism of control over the provision of data in monitoring the educational system were received.

To resolve the problem, it is proposed to implement the system of civil control over both universities and the regulator activities with some sort of monetization of such relations.

In this case, it is necessary:

1. to increase the complainant's rights, enabling the opportunity to appeal against Rosobrnadzor actions at any stage of administrative offense proceedings;

2. to change the scope of power of the regulator with fixing the responsibility to consider cases on administrative offenses in the field of higher education;

3. to impose the responsibility of Rosobrnadzor officials for violations of the law during administrative offense proceedings;

4. to stimulate complainants for the revealed offenses through the bonus (as a part of the amount of the fine);

5. to pay a similar bonus to Rosobrnadzor officials to balance their increased responsibility;

6. to align the statutory requirements for the activities in the field of higher education with the Code of the Russian Federation on Administrative Offenses to provide the penalties mostly in the form of fines for the violation of each administrative requirement for the heads of universities;

7. to implement the unified information system of monitoring, which can verify the indicators provided by universities;

8. to oblige universities to provide the relevant documents confirming the achievement of stated indicators or other verified sources of data to complete the previous point employing information system.

Nevertheless, taking into account the experience of foreign countries, the implementation of these key points or the proclaimed goals of the reform of control and supervision activities in the field of higher education as a whole will be successful only with the hard lobbying by independent organizations. Otherwise, the regulators represented by Rosobrnadzor and the Ministry of Education and Science of the Russian Federation will act exceptionally in their interests. Conducted in the article, the analysis of the announced reform of control and supervision in the field of higher education does not inspire optimism in this regard.

Authors' Contributions: Kozyrev, M. S.: conception and design, acquisition of data, analysis and interpretation of data, drafting the article, critical review of important intellectual content. Jukova, E. E.: conception and design, acquisition of data, analysis and interpretation of data, drafting the article, critical review of important intellectual content. Palekhova, P. V.: conception and design, acquisition of data, analysis and interpretation of data, drafting the article, critical review of important intellectual content. Shumarov, A. P.: conception and design, acquisition of data, analysis and interpretation of data, drafting the article, critical review of important intellectual content. Faizulin, R. V.: conception and design, acquisition of data, analysis and interpretation of data, drafting the article, critical review of important intellectual content. All authors have read and approved the final version of the manuscript.

Ethics Approval: Not applicable.

Acknowledgments: Not applicable.

\section{REFERENCES}

Aleksandrov, O. V. (2019). "Regulyatornyye gil'otiny": mezhdunarodnyy opyt ustraneniya prepyatstviy dlya biznesa i investirovaniya ["Regulatory Guillotines": International experience in removing barriers to business and investment]. Torgovaya politika, 1(17), 107-119.

Ambler, T., Chittenden, F., \& Xiao, D. (2007, April). The burden of regulation: Who is watching out for us? The British Chambers of Commerce. Available: http://regulatoryreform.com/wp-content/uploads/2015/02/UK-The-burden-ofregulation-BCC-April-2007.pdf 
Analytical Centre under the Government of the Russian Federation. (2021, October 26). Mikhail Mishustin utverdil meropriyatiya po tsifrovoy transformatsii v sfere gosupravleniya [Mikhail Mishustin has adopted measures for digital transformation in public administration]. Available: https://knd.ac.gov.ru/5450/

Aniskina, N. N., Malinina, T. V., \& Lalaeva, Z. A. (2019). "Regulyatornyye gil'otiny": mezhdunarodnyy opyt ustraneniya prepyatstviy dlya biznesa i investirovaniya ["Regulatory guillotines": What awaits additional professional education]. Dopolnitel'noye professional'noye obrazovaniye v strane i mire, 4(46), 1-6.

Arapov, O. G., Arapova, E. A., Volnyakova, O. A., \& Solodukhin, D. V. (2018). Philosophical problems of education in the Russian natural scientific thought. Russian Technological Journal, 6(6), 84-100. https://doi.org/10.32362/2500-316X2018-6-6-84-100.

Astakhov, A. M. (2019). "Regulyatornaya gil'otina" v sfere malogo biznesa, prioritety i oriyentiry [“Regulatory guillotine" in the field of small business, priorities and guidelines]. In: Yachmenevov, V. M., Vorobets, T. I., Timaev, R. A. (Eds.). Issledovaniye, sistematizatsiya, kooperatsiya, razvitiye, analiz sotsial'no-ekonomicheskikh sistem $v$ oblasti ekonomiki i upravleniya (ISKRA - 2019). Sbornik trudov II Vserossiyskoy shkoly-simpoziuma molodykh uchenykh [Research, systematization, cooperation, development, analysis of socio-economic systems in the field of economics and management (ISKRA - 2019). Proceedings of the II All-Russian school-symposium of young scientists], Simferopol: Izdatel'stvo Tipografiya "Arial", pp. 37-40.

Constitutional Court of the Russian Federation. (2014). Postanovleniye Konstitutsionnogo Suda RF ot 23 sentyabrya 2014 g. No. 24-P po delu o proverke konstitutsionnosti chasti 1 stat'i 6.21 Kodeksa Rossiyskoy Federatsii ob administrativnykh pravonarusheniyakh v svyazi s zhaloboy grazhdan N.A. Alekseyeva, Ya.N. Yevtushenko i D.A.Isakova [Ruling of the Constitutional Court of the Russian Federation of September 23, 2014 No. 24-P On the review of the constitutionality of Article 6.21(1) of the Code of Administrative Offences of the Russian Federation in connection with the complaint lodged by citizens N.A. Alekseev, Ya.N. Yevtushenko and D.A. Isakov]. Available: http://doc.ksrf.ru/decision/KSRFDecision173469.pdf

Darda, I. V., \& Zernov, V. A. (2020). Perspektivy gosudarstvennoy akkreditatsii vuzov v kontekste "regulyatornoy gil'otiny" [Prospects for state accreditation of universities in the context of the "regulatory guillotine"]. Vyssheye obrazovaniye segodnya, 6, 2-7.

Department of the Taoiseach. (2009, June). Revised RIA guidelines. How to conduct a Regulatory Impact Analysis. Available: http://regulatoryreform.com/wp-content/uploads/2015/02/Ireland-

Revised_RIA_Guidelines_June_2009.pdf

Didikin, A. B. (2019). “Regulyatornaya gil'otina” v mekhanizme vzaimodeystviya rossiyskogo gosudarstva i obshchestva ["Regulatory guillotine" in the mechanism of interaction between the Russian state and society]. Akademik, 2, 10-15.

Federal Service for Supervision of Education and Science. (2017). Rosobrnadzor provel eksperiment po nezavisimoy proverke znaniy studentov [Rosobrnadzor conducted the experiment in independent assessment of students' knowledge]. Available: http://obrnadzor.gov.ru/news/rosobrnadzor-provel-eksperiment-po-nezavisimoj-proverkeznanij-studentov/

Federal Service for Supervision of Education and Science. (2019). Rosobrnadzor rasskazal o novykh podkhodakh k kontrol'no-nadzornoy deyatel'nosti v ramkakh "regulyatornoy gil'otiny" [Rosobrnadzor spoke about new approaches to control and supervisory activities within the framework of the "regulatory guillotine"]. Available: http://obrnadzor.gov.ru/ru/press_center/news/index.php?id_4=7189

Feynberg, A. (2019, January 15). Gil'otina ot pravitel'stva: kak vlasti khotyat snizit' trebovaniya k biznesu [Guillotine from the government: How the authorities want to reduce the requirements for business]. RBK. Available: https://www.rbc.ru/economics/15/01/2019/5c3df76f9a7947214d11adcf

Filippov, V. M., Gol'tyapina, I. Yu., Podgornaya, S. O., \& Manokhina, T. V. (2020). Mekhanizm "regulyatornoy gil'otiny" v obrazovanii [The mechanism of the "regulatory guillotine" in education]. Innovatsionnaya ekonomika i obshchestvo 1(27), 72-77.

Government of the Russian Federation. (2013, July 10). Postanovleniye Pravitel'stva RF ot 10 iyulya 2013 g. No. 582 "Ob utverzhdenii Pravil razmeshcheniya na ofitsial'nom sayte obrazovatel'noy organizatsii v informatsionnotelekommunikatsionnoy seti "Internet" i obnovleniya informatsii ob obrazovatel'noy organizatsii" [Decree of the Government of the Russian Federation of July 10, 2013 No. 582 "On the adoption of the Rules for posting on the official website of educational organizations in information and telecommunication network "Internet" and the updating of information on educational organization"]. Sobranie Zakonodatel'stva Rossiiskoi Federatsii [SZ RF] [Collection of Legislation of the RF] 22.07.2013, No. 29, Item 3964. 
Government of the Russian Federation. (2013, August 5). Postanovleniye Pravitel'stva RF ot 5 avgusta 2013 g. No. 662 "Ob osushchestvlenii monitoringa sistemy obrazovaniya" (s izmeneniyami i dopolneniyami) [Decree of the Government of the Russian Federation of August 5, 2013 No. 662 "On monitoring the education system" (with amendments and additions)]. Sobranie Zakonodatel'stva Rossiiskoi Federatsii [SZ RF] [Collection of Legislation of the RF] 19.08.2013, No. 33, Item 4378.

Government of the Russian Federation. (2019, May 29). Plan meropriyatiy (“dorozhnaya karta”) po realizatsii mekhanizma "regulyatornoy gil'otiny" ot 29 maya 2019 g. No. 4714p-P36 [Action plan ("road map") for implementing the "regulatory guillotine" mechanism of May 29, 2019 No. 4714p-P36]. Available: https://knd.ac.gov.ru/wpcontent/uploads/2019/09/road map.pdf

Government of the Russian Federation. (2019, July 4). Perechen' federal'nykh organov ispolnitel'noy vlasti, osushchestvlyayushchikh funktsii po normativno-pravovomu regulirovaniyu v sferakh osushchestvleniya gosudarstvennogo kontrolya (nadzora), i federal'nykh organov ispolnitel'noy vlasti, osushchestvlyayushchikh kontrol'no-nadzornyye funktsii, uchastvuyushchikh v realizatsii mekhanizma "regulyatornoy gil'otiny", vidov federal'nogo gosudarstvennogo kontrolya (nadzora), osushchestvlyayemykh federal'nymi organami ispolnitel'noy vlasti, na kotoryye dolzhen byt' rasprostranen mekhanizm "regulyatornoy gil'otiny" [List of federal executive bodies exercising regulatory functions in the areas of state control (supervision) and federal executive bodies exercising control and supervisory functions involved in the implementation of the "regulatory guillotine" mechanism, types of federal state control (supervision) exercised by federal executive bodies to which the "regulatory guillotine" mechanism should be extended]. Available:

http://static.government.ru/media/files/xcAOZszIPnsB9jDDLj5AQoymiX3QIwfs.pdf

Intrefaks. (2019, February 20). Putin prizval s 2021 goda prekratit' deystviye starykh normativnykh aktov v sfere kontrolya i nadzora [Putin called from 2021 to terminate the old regulations in the field of control and supervision]. Available: https://www.interfax.ru/russia/651347

Japan fact sheet. (2015). Drastic structural reform, a new driving force for growt. Regulatory reform. Available: http://regulatoryreform.com/wp-content/uploads/2015/02/Japan-Regulatory-Reform-Fact-Sheet-2010.pdf (accessed March 8, 2021).

Kokhanov, R. I. (2016). Zarubezhnyy opyt vzaimodeystviya gosudarstvennykh i obshchestvennykh institutov po upravleniyu kachestvom vysshego obrazovaniya [Foreign experience of interaction between state and public institutions for quality management in higher education]. Molodoy uchenyy, 20(124), 520-528.

Korenkov, I. P., Okhrimenko, S. E., Samoilov, A. S., Shestopalov, N. V., \& Prokhorov, N. I. (2019). A differentiated approach to hygienic indices in evaluating the activity of radiation facilities. Gigiena i Sanitariya, 98(3), 256-260. https://doi.org/10.18821/0016-9900-2019-98-3-256-260

Kotsanopoulos, K. V., \& Arvanitoyannis, I. S. (2017). The role of auditing, food safety, and food quality standards in the food industry: A review. Comprehensive Reviews in Food Science and Food Safety, 16(5), 760-775.

https://doi.org/10.1111/1541-4337.12293

Kozyrev, M. S., Bogacheva, T. V., Jukova, E. E., \& Palekhova, P. V. (2019). Analysis of management of higher education institutions. European Journal of Contemporary Education, 8(4), 801-809. https://doi.org/10.13187/ejced.2019.4.801

Litvinova, Yu. M., \& Romanova, A. S. (2020). "Regulyatornaya gil'otina" kak effektivnyy mekhanizm administrativnoy reformy [The "regulatory guillotine" as an efficient mechanism of the administrative reform]. In: Gogolevskaya, E. B. (Ed.). Problemy zashchity prav: istoriya i sovremennost'. Materialy XIV mezhdunarodnoy nauchno-prakticheskoy konferentsii [Problems of rights protection: History and modernity. Proceedings of the XIV International scientific and practical conference]. St. Petersburg: Leningrad State University named after A.S. Pushkin, pp. 380-383.

Lopatina, T. M. (2020). Rol' obshchestvennogo kontrolya v sovremennykh usloviyakh [The role of public control in modern conditions]. Rossiyskaya yustitsiya, 4, 49-52.

Manyushis, A. Yu. (2020). Nezavisimaya otsenka kachestva obrazovaniya: chego my zhdem ot "regulyatornoy gil'otiny"? [An independent assessment of the quality of education: what do we expect from the "Regulatory guillotine"?]. Nauchnyye trudy Vol'nogo ekonomicheskogo obshchestva Rossii, 222(2), 380-406. https://doi.org/10.38197/2072-2060-2020-222-2-380-406

Margolin, A. M. (2019). Monitoring vuzov: vsevidyashcheye oko regulyatornoy gil'otiny [University monitoring: The allseeing eye of the regulatory guillotine]. Obrazovatel'naya politika, 1-2(77-78), 67-75.

Martynov, A. V. (2019). Perspektivy primeneniya mekhanizma "regulyatornoy gil'otiny" pri reformirovanii kontrol'nonadzornoy deyatel'nosti [Prospects for the application of the "regulatory guillotine" mechanism in reforming control and supervisory activities]. Vestnik Nizhegorodskogo universiteta im. N.I. Lobachevskogo, 5, 143-165. 
Maslennikova, E. V., Dobrolyubova, E. I., \& Yuzhakov, N. V. (2020). Effectiveness of control and enforcement activities in selected areas: Statistics and sociology. Ekonomicheskaya politika, 15(1), 90-107. https://doi.org/10.18288/19945124-2020-1-90-107

Mitrokhin, O. V. (2019). Interaction between state and non-state organizations while monitoring sanitary and epidemiological safety. Voprosy gosudarstvennogo i munitsipalnogo upravleniya-public administration, 113-132,4.

Motova, G. N. (2020). Guards or conductors? New requirements for accreditation agencies on education quality assurance. Vysshee Obrazovanie v Rossii, 29(6), 9-21. https://doi.org/10.31992/0869-3617-2020-6-9-21

Mutsalov, Sh. Sh., \& Arsamirzayeva, T. A. (2021). "Regulatory guillotine" in the sphere of transformation of legal regulation of certain education issues in the Russian Federation. International Research Journal, 1(103), 86-89. https://doi.org/10.23670/IRJ.2021.103.1.103

Ondee, P., \& Pannarunothai, S. (2008). Stakeholder analysis: Who are the key actors in establishing and developing Thai independent consumer organizations?". World Academy of Science, Engineering and Technology International Journal of Humanities and Social Sciences, 2(8), 907-917.

Parker, D., \& Kirkpatrick, C. (2012, August). Measuring regulatory performance. The economic impact of regulatory policy: A literature review of quantitative evidence. OECD Expert Paper No. 3. Available: https://www.oecd.org/gov/regulatory-policy/3_Kirkpatrick\%20Parker\%20web.pdf

Red'ko, S. V. (2020). K voprosu o printsipakh peresmotra sanitarno-epidemiologicheskikh trebovaniy v usloviyakh realizatsii mekhanizma "regulyatornoy gil'otiny" [On the issue of the principles of revision of sanitary and epidemiological requirements in the context of the implementation of the mechanism of "regulatory guillotine"]". In: Popova, A. Yu., Zaitseva, N. V. (Eds.). Analiz riska zdorov'yu - 2020 sovmestno s mezhdunarodnoy vstrechey po okruzhayushchey srede i zdorov'yu Rise-2020 i kruglym stolom po bezopasnosti pitaniya. Materialy X Vserossiyskoy nauchno-prakticheskoy konferentsii s mezhdunarodnym uchastiyem. V 2-kh tomakh [Health Risk Analysis 2020 in conjunction with the International Meeting on Environment and Health RISE-2020 and the Nutrition Security Roundtable. Materials of X All-Russian scientific and practical conference with international participation. In 2 volumes]. Perm: Perm National Research Polytechnic University, pp. 95-99.

Safonkina, S. G., Ivanenko, A. V., \& Kuchma, V. R. (2012). Scientific and practical substantiation of the methodology for sanitary-epidemiological auditing educational institutions. Gigiena i Sanitariya, 6, 46-48.

Sokolov, V. (2020). Monitoring of legal regulation of educational activities in terms of legal practice in implementing the "Regulatory Guillotine" in the field of education. Science Governance and Scientometrics Journal, 15(4), 589-626. https://doi.org/10.33873/2686-6706.2020.15-4.589-626

Sovremennyy predprinimatel'. (2019, January 17). Dmitriy Medvedev schitayet, chto trebovaniya k biznesu zavysheny [Dmitry Medvedev believes that the requirements for business are overstated]. Available:

https://spmag.ru/news/dmitriy-medvedev-schitaet-chto-trebovaniya-k-biznesu-zavysheny

State Duma of the Federal Assembly of the Russian Federation. (2001). Kodeks ob administrativnykh pravonarusheniyakh RF ot 30 dekabrya 2001 g. No. 195-FZ (s izmeneniyami na 21 dekabrya 2021 goda) [The Code of the Russian Federation on Administrative Offences of December 30, 2001 No. 195-FZ (as amended on December 21, 2021)]. Sobranie Zakonodatel'stva Rossiiskoi Federatsii [SZ RF] [Collection of Legislation of the RF] 07.01.2002, No. 1 (Part I), Item 1.

State Duma of the Federal Assembly of the Russian Federation. (2008). Federal'nyy zakon ot 26 dekabrya 2008 g. No. 294-FZ “O zashchite prav yuridicheskikh lits i individual'nykh predprinimateley pri osushchestvlenii gosudarstvennogo kontrolya (nadzora) i munitsipal'nogo kontrolya" [Federal Law of December 26, 2008 No. 294-FZ "On protection of the rights of legal entities and individual entrepreneurs in implementation of state control (supervision) and municipal control"]. Sobranie Zakonodatel'stva Rossiiskoi Federatsii [SZ RF] [Collection of Legislation of the RF] 29.12.2008, No. 52 (Part I), Item 6249.

State Duma of the Federal Assembly of the Russian Federation. (2012). Federal'nyy zakon ot 29 dekabrya 2012 g. No. 273-FZ “Ob obrazovanii v Rossiyskoy Federatsii" [The Federal Law of December 29, 2013 No. 273-FZ "On education in the Russian Federation" of December 29, 2013 No. 273-FZ]. Sobranie Zakonodatel'stva Rossiiskoi Federatsii [SZ RF] [Collection of Legislation of the RF] 31.12.2012, No. 53 (Part I), Item 7598.

Supreme Court of the Russian Federation. (2016). Opredeleniye Verkhovnogo Suda RF ot 26 dekabrya 2017 g. No. $304-$ AD17-12725 po delu No. A70-16163/2016 [Determination of the Supreme Court of the Russian Federation of December 26, 2017 No. 304-AD17-12725 in case No. A70-16163/2016]. Available: https://kad.arbitr.ru/Document/Pdf/6bade30f-ce8a-4840-ae54-745da4aacd75/a39b88b6-5989-423b-af957643ca6bdb18/A70-16163-2016_20171226_Opredelenie.pdf?isAddStamp=True 
Tsypkina, I. S. (2019). K voprosu o tselesoobraznosti realizatsii mekhanizma "regulyatornoy gil'otiny" primenitel'no k trudovomu zakonodatel'stvu [On the feasibility of implementing the "regulatory guillotine" mechanism in relation to labor legislation]. Vestnik Universiteta imeni O.Ye. Kutafina (MGYUA), 11(63), 77-82.

Yuzhakov, V. N., Dobrolyubova, E. I., \& Pokida, A. N. (2019). Inspection and regulatory enforcement reform: Evaluation from the citizen perspective. Public Administration Issues, 2, 71-92.

Yuzhakov, V. N., Dobrolyubova, E. I., Pokida, A. N., \& Zybunovskaya, N. V. (2020). Evaluating performance of regulatory enforcement activities by businesses: Key trends. Public Administration, 2, 32-53.

Received: 11 September 2021 | Accepted: 10 November 2021 | Published: 31 January 2022

This is an Open Access article distributed under the terms of the Creative Commons Attribution License, which permits unrestricted use, distribution, and reproduction in any medium, provided the original work is properly cited. 